\title{
Soluble cerebral proteins in normal and oedematous brain
}

\author{
J. N. CUMINGS \\ From the Department of Chemical Pathology, the Institute of Neurology, \\ The National Hospital, Queen Square, London, W.C.1
}

SYNOPSIS The soluble cerebral proteins of cortex and white matter from normal brains of adults and infants and of oedematous brain tissue have been subjected to starch electrophoresis. The protein patterns with their nitrogen, lactic dehydrogenase, and glutamic oxalacetic transaminase contents were estimated. The normal patterns of these substances have been compared with the findings of workers using other methods of electrophoresis.

Oedematous brains have been shown to possess an albumin band with an increase in lactic dehydrogenase in some globulin bands. These findings are discussed in relation to the mode and site of production of oedema.

The electrophoretic pattern of the proteins of the various body fluids has been and still is being extensively studied. Relatively few similar examinations of the soluble cerebral proteins have been performed in normal brain and even fewer in disease processes.

Robertson (1960) has recently recorded his findings from normal brains and made some comparison with the results published by a few other authors. Originally paper electrophoresis was carried out by Kaps (1954), Palladin (1957), and Tomonaga (1959) and this was the method used by Robertson. Van Sande, Karcher, and Lowenthal (1959) have used agar as well as paper electrophoresis, while Kessel (1959) has examined tissue proteins from the liver and kidney by agar electrophoresis and Schwarzmann (1959) has applied starch electrophoresis to extracts of the liver and stomach.

This paper records the results of the electrophoresis of soluble cerebral protein from normal brains and from oedematous cerebral tissue utilizing the starch technique of Smithies. Further, the amounts of lactic dehydrogenase (L.D.H.), glutamic oxalacetic transaminase (G.O.T.), and of nitrogen in the various protein fractions have been estimated. A somewhat similar but less detailed study of the brains of young infants has been performed. A few of the earliest studies have already been briefly mentioned (Cumings, 1959).
MATERIAL AND METHODS

Brains have been obtained at necropsy performed less than 24 hours after death and portions of normal and abnormal cortex and cerebral white matter carefully dissected out immediately. Fourteen portions of frontal lobe, five of temporal, nine of parietal, 17 of occipital, and two each from the basal ganglia and the pons were initially examined. The areas showing oedema in brains from patients with cerebral tumours were the frontal and temporal lobes (two each) and the occipital and parietal lobes (one each).

For the enzyme studies further brains were used, in three of which only L.D.H. was estimated and 10 brains in which L.D.H., G.O.T., and nitrogen were estimated. One oedematous brain was examined for L.D.H. only, while five such brains were tested for their contents of L.D.H., G.O.T., and nitrogen, and in one infarcted brain from vascular occlusion all these examinations were made. The brains of children at full term, at 2, 3, and 8 months and at 6 years were examined by electrophoresis as well as for enzymes.

After separation of white matter and of cortex $5 \mathrm{~g}$. of the former was extracted with $10 \mathrm{ml}$. of $0.3 \mathrm{M}$. sucrose. Either similar amounts or more frequently $5 \mathrm{~g}$. of cortex was extracted with $5 \mathrm{ml}$. of sucrose of the same molar strength. The extracts after centrifugation at $12,000 \mathrm{~g}$. in a refrigerated centrifuge at $0^{\circ}$ to $4^{\circ} \mathrm{C}$. were concentrated by negative pressure at $4^{\circ} \mathrm{C}$., recentrifuged if necessary, and, after measurement of the volume, a portion was examined by starch electrophoresis.

The method employed was that of Smithies (1955), using both buffer and staining procedures as recommended by him. Electrophoresis was carried out overnight (16-18 hours) at a voltage of 120 and with a current 
of $0.44 \mathrm{MA}$. per $\mathrm{cm}$. width. The gel was marked along one longitudinal edge with a serrated metal cutter so that after the staining of one longitudinal section for protein, the fractions could be accurately located in the remaining unstained gel. This half of the gel was then subdivided into from six to 10 portions in which were specific protein bands. Each portion was placed within a small glass cylinder upon a fritted filter sealed within the tube and the whole placed within a conical centrifuge tube. After freezing solid overnight, the tubes were centrifuged at about 2,000 r.p.m. The volume of the protein-containing fluid was measured and aliquots were examined for L.D.H., G.O.T., and for total nitrogen, which substances were also estimated in the original concentrate.

Lactic dehydrogenase was estimated by the method of Wróblewski and LaDue (1955), G.O.T. by King (1958), and total nitrogen by Greenberg's method (1929), and a microKjeldahl method was used to confirm the degree of accuracy, which was within $2 \%$.

\section{RESULTS}

The number and site of the various protein fractions has varied from case to case and area to area. Usually between two and four bands migrate cathodally as the $\gamma$ globulins of blood sera, while from seven to 10 bands migrate towards the anode. Almost invariably two and even three pre-albumin bands are present. Figure 1 is a photograph of 10 starch gels from various areas of both white and grey matter. Definite differences can be noted between the different areas of the cerebrum; for instance, more bands are present in the occipital lobes. However, there is often slightly more albumin and pre-albumin in the cortex than in the white matter, as well as more protein in fractions 3 and migrating anodally. However, the actual amounts of protein can more readily be seen in Figs. 5 and which are discussed later.

The findings in the oedematous brains are illus $\frac{\bar{\alpha}}{\frac{\widehat{C}}{\sigma}}$ trated in Fig. 2, together with those in sera frong three of the patients. Two points are striking; firsto there is a very marked content of albumin in the cerebral white matter exactly matching the site oP serum albumin. This band does not obscure the pre-albumin band. Secondly, the cerebral cortew does not always show this albumin; in fact, in onl吾 half of the brains examined could this feature be demonstrated. These changes can also be seen if Figs. 7 and 8 which are described later.

Figs. 3 and 4 show the results obtained of electrophoresis of the soluble cerebral proteins frons young infants. The protein pattern is not so well. demonstrated in that the bands tend not to be se well separated, and fewer distinct bands can be found. However, more protein is extractable from these brains than from those of adults as will be् seen from Tables I and II.

Considering the enzyme studies, examples of the results are seen in Figs. 5 and 6 . These illustrate the percentage protein contents of the bands an $\bar{\Phi}$ the relative distribution of L.D.H. and G.O.T. 送 the bands. The amounts of these substances in the original concentrate related to $1 \mathrm{~g}$. of fresh brain ar $\overrightarrow{\vec{\theta}}$ also given. The quantity of nitrogen per $g$. of fres $\vec{P}$ brain was fairly constant for both white matter an cortex, usually being between 0.15 and $0.25 \mathrm{mg}$. for

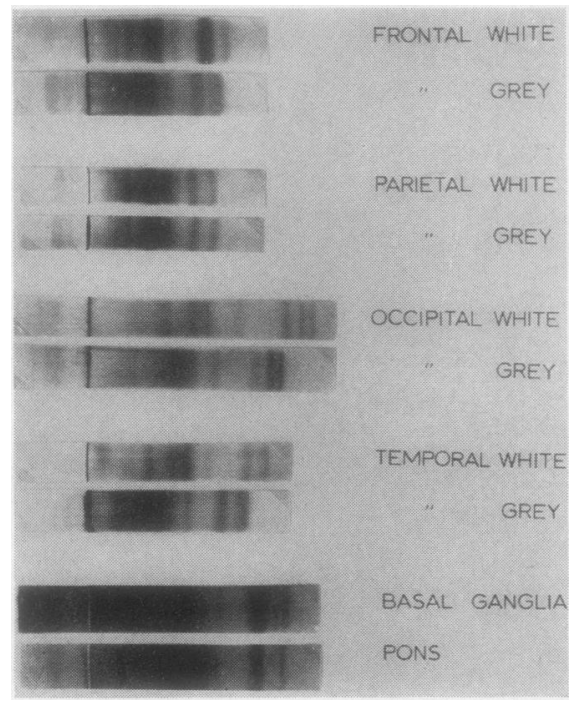

FIG. 1

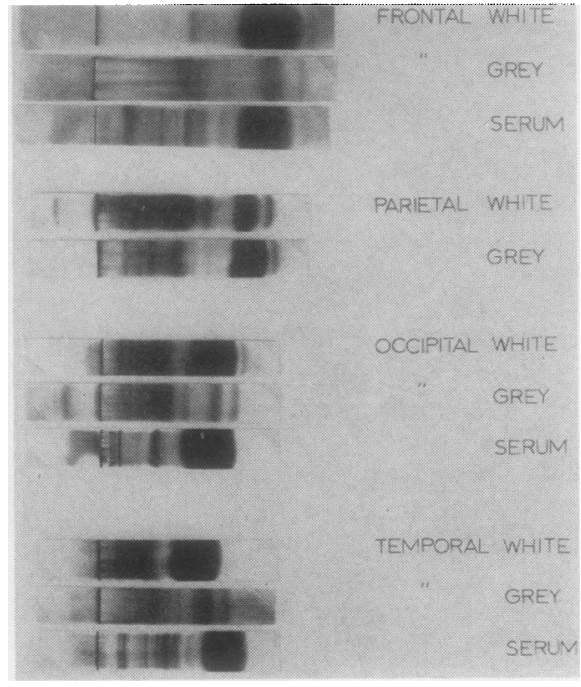

FIG. 2
FIG. 1. Solub每. cerebral proteins in normal braiks?

FIG. 2. Soluble cerebral proteins in oedematous brain. 


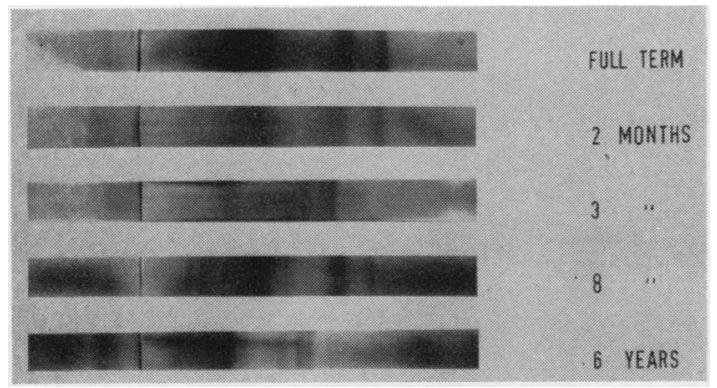

FIG. 3. Soluble cerebral proteins in cerebral white matter.

the former and 0.5 and 0.75 for the latter. Considerable amounts of L.D.H. were located within the first four protein bands travelling anodally from the site of insertion, while none was ever present in the $\gamma$ globulin, albumin, or pre-albumin fractions. By contrast, G.O.T. was present in small amounts and was distributed somewhat unevenly over all the protein bands.

Similar studies of oedematous brain are illustrated in Figs. 7 and 8. There is seen to be an increased total protein as indicated by nitrogen content and by the presence of a marked albumin band in both white matter and cortex. There is a definite increase in L.D.H. which is present in the same bands as in a normal brain, while no increase in G.O.T. is seen. Other samples of oedematous brain examined showed very similar results, although, on two occasions only, very small quantities of L.D.H. were found in the albumin band. In no case was the total amount of G.O.T. increased. The infarcted brain showing slightly increased water content with a

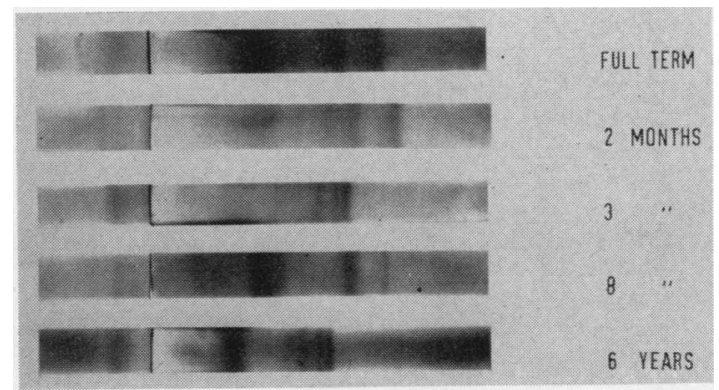

FIG. 4. Soluble cerebral proteins in cortex.

small albumin band in both cortex and white matter yet demonstrated no alteration from the normal in content or in distribution of these two enzymes (Figs. 9 and 10).

The brains of infants showed results that are given in Tables I and II. In general there is a steady increase in both L.D.H. and G.O.T. per mg. of nitrogen up to 8 months of age when figures similar to those of the adult were obtained. The lower L.D.H. at 6 years in both cortex and white matter is unexplained and may be a fortuitous result, or it may be that the figure at 8 months is too high, for this infant died of an acute pyogenic infection.

\section{DISCUSSION}

Examinations of the soluble cerebral proteins were carried out first by paper electrophoresis by Kaps (1954). Hofmann and Schinko (1956), Robertson (1957), and Karcher, Lowenthal, and van Sande (1958), and some six or so different bands which

TABLE I

ENZYMES IN FRESH CEREBRAL WHITE MATTER

\begin{tabular}{|c|c|c|c|c|c|c|}
\hline \multirow[t]{2}{*}{ Age } & \multirow{2}{*}{$\begin{array}{l}\% \text { Water } \\
\text { Content }\end{array}$} & \multirow{2}{*}{$\begin{array}{l}\text { mg. } N_{2} \\
\text { per g. Brain }\end{array}$} & \multicolumn{2}{|c|}{ G.O.T. in Units } & \multicolumn{2}{|c|}{ L.D.H. in Units } \\
\hline & & & per g. Brain & per mg. $N_{2}$ & per g. Brain & per mg. $N_{2}$ \\
\hline $\begin{array}{l}\text { Stillborn } \\
2 \text { months } \\
3 \text { months } \\
8 \text { months } \\
6 \text { years }\end{array}$ & $\begin{array}{l}87 \cdot 4 \\
86 \cdot 0 \\
84 \cdot 1 \\
78 \cdot 3 \\
71 \cdot 0\end{array}$ & $\begin{array}{l}0.82 \\
0.20 \\
0.31 \\
0.74 \\
0.82\end{array}$ & $\begin{array}{r}29 \\
7 \\
19 \\
52 \\
86\end{array}$ & $\begin{array}{r}35 \\
35 \\
61 \\
70 \\
105\end{array}$ & $\begin{array}{r}6,160 \\
3,130 \\
4,000 \\
29,000 \\
3,600\end{array}$ & $\begin{array}{r}7,510 \\
15,600 \\
12,900 \\
39,000 \\
4,400\end{array}$ \\
\hline
\end{tabular}

TABLE II

ENZYMES IN FRESH CEREBRAL CORTEX

\begin{tabular}{|c|c|c|c|c|c|c|}
\hline \multirow[t]{2}{*}{ Age } & \multirow{2}{*}{$\begin{array}{l}\% \text { Water } \\
\text { Content }\end{array}$} & \multirow{2}{*}{$\begin{array}{l}\text { mg. } N_{x} \\
\text { per } g . \text { Brain }\end{array}$} & \multicolumn{2}{|c|}{ G.O.T. in Units } & \multicolumn{2}{|c|}{ L.D.H. in Units } \\
\hline & & & per g. Brain & per $m g . N_{2}$ & per g. Brain & per $m g . N_{2}$ \\
\hline $\begin{array}{l}\text { Stillborn } \\
2 \text { months } \\
3 \text { months } \\
8 \text { months } \\
6 \text { years }\end{array}$ & $\begin{array}{l}87 \cdot 4 \\
85 \cdot 8 \\
85 \cdot 6 \\
83 \cdot 8 \\
83 \cdot 1\end{array}$ & $\begin{array}{l}0 \cdot 86 \\
0 \cdot 76 \\
0 \cdot 70 \\
1 \cdot 18 \\
2 \cdot 74\end{array}$ & $\begin{array}{r}26 \\
45 \\
39 \\
88 \\
377\end{array}$ & $\begin{array}{r}30 \\
59 \\
56 \\
75 \\
137\end{array}$ & $\begin{array}{r}6,800 \\
9,890 \\
8,700 \\
42,215 \\
7,860\end{array}$ & $\begin{array}{r}7,910 \\
13,010 \\
12,430 \\
35,800 \\
2,870\end{array}$ \\
\hline
\end{tabular}




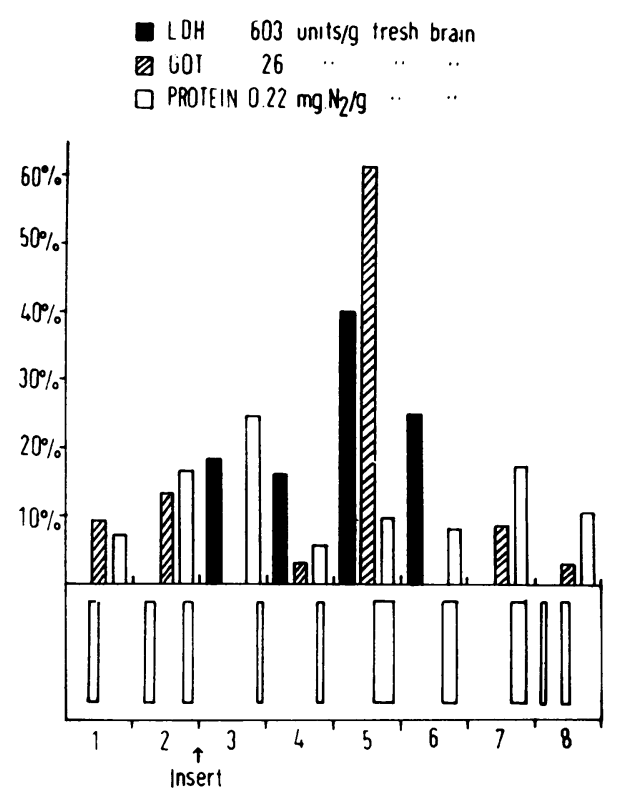

FRACTIONS

FIG. 5. Normal white matter.
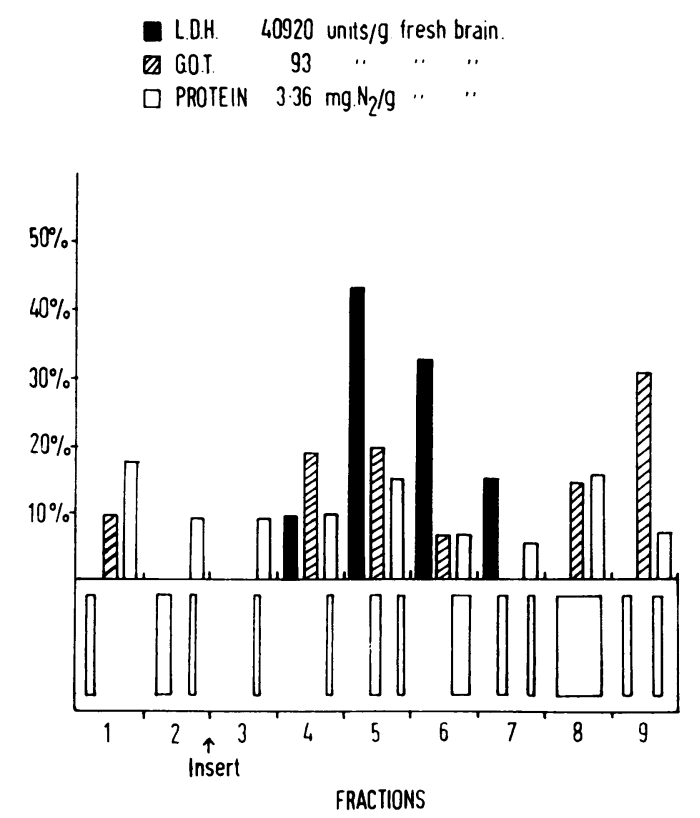

FIG. 7. Oedematous cerebral white matter.
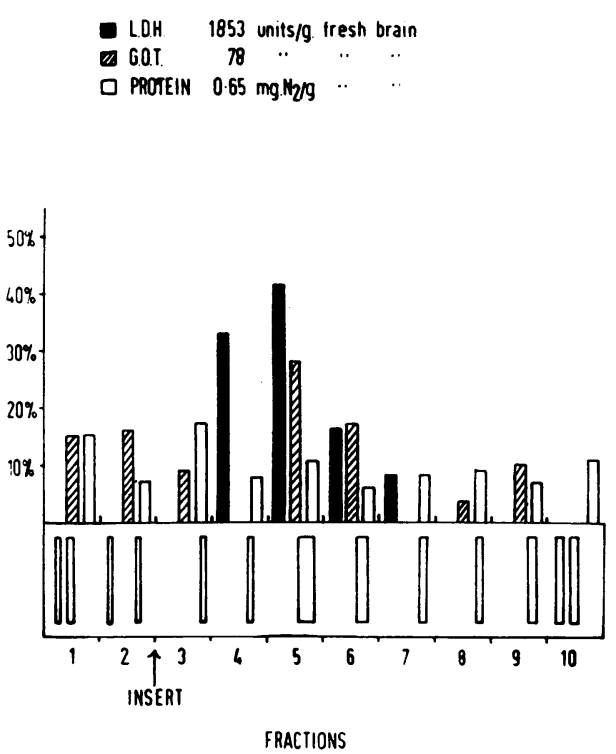

FIG. 6. Normal cortex.

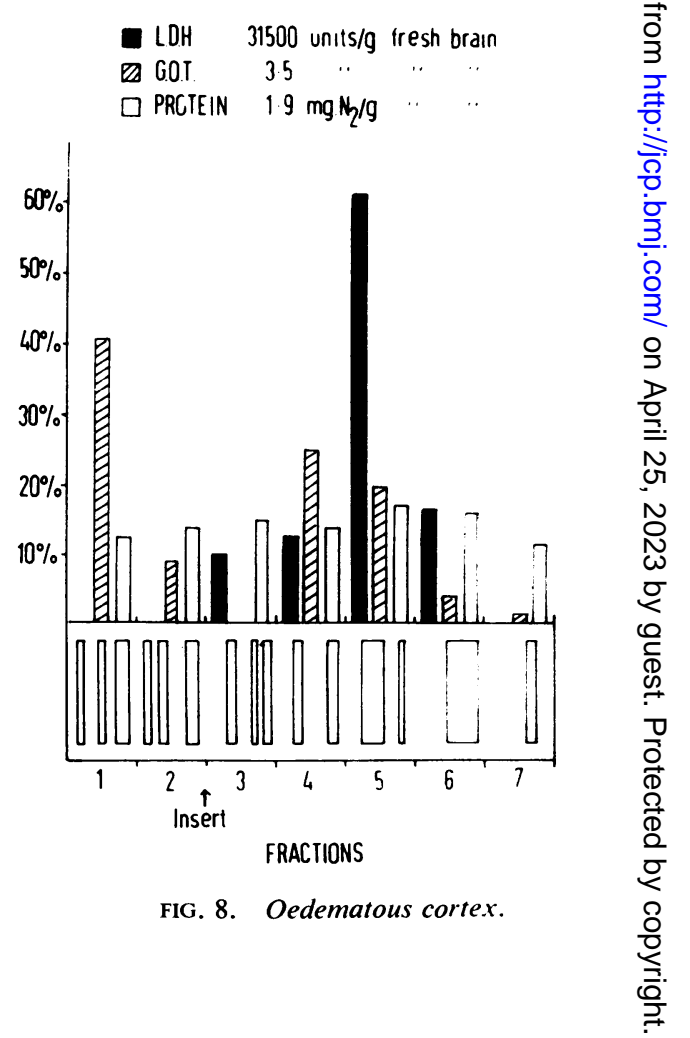



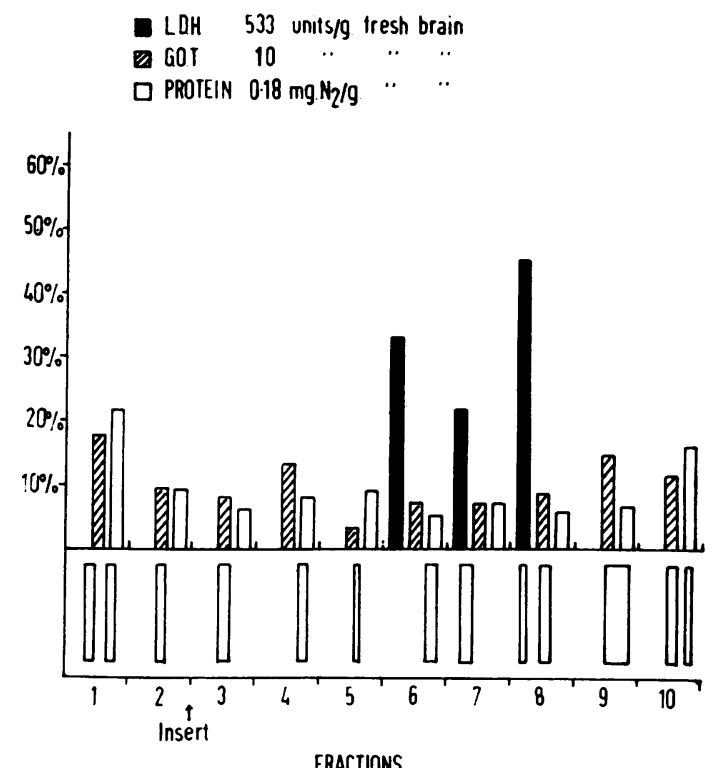

FIG. 9. Infarcted cerebral white matter.

were not well defined were found. Later other workers-Booij (1957), Kiyota (1959a), Tomonaga (1959)-found more fractions and these were frequently designated as being $\alpha, \beta$, and $\gamma$ globulin as well as albumin and pre-albumin. Recently Robertson (1960) by paper electrophoresis found one $\gamma$ globulin, three $\alpha$ and three $\beta$ globulins, one albumin, and two pre-albumin bands. He estimated the protein content of each fraction and reported more of fraction 4 in the cortex than in the white matter and more of fraction 7 , probably an $\alpha$ globulin, in white than in grey matter. The results that have been found in starch would be in general agreement with these findings. Karcher et al. in two papers in 1959 examined these proteins by agar electrophoresis and they have described some seven to nine fractions in various areas and their results are very similar to those recorded here, but they did not obtain such a good separation of the fractions. Their method does, however, possess the advantage that a curve can be obtained by scanning the agar strip in a densitometer, whereas it has been necessary here to estimate the nitrogen content of the fractions separately. They found more pre-albumin and albumin than was found by the method recorded here. However, the degree of separation obtained on paper is not always very satisfactory.

Other organs besides the brain show soluble proteins, as Schwarzmann (1959) showed for the liver and stomach. He found up to 15 fractions for

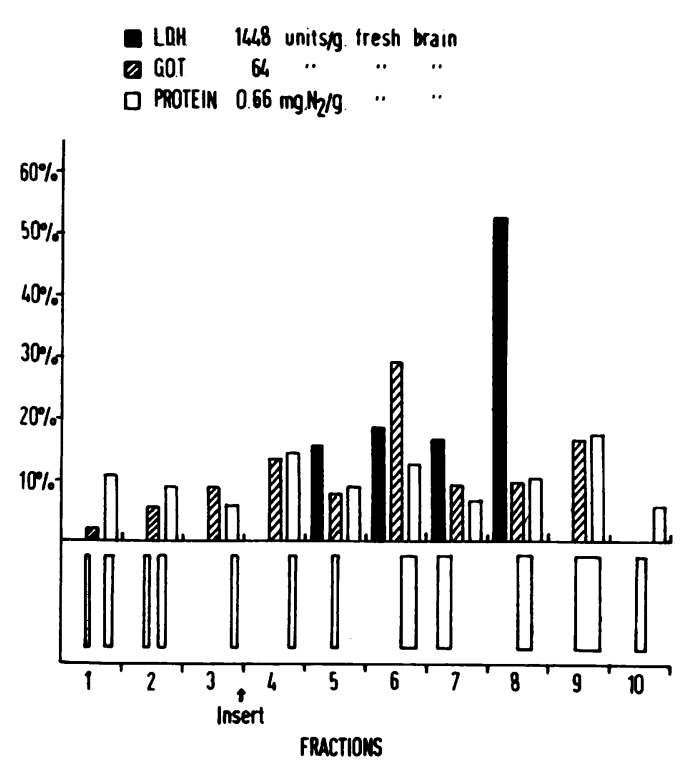

FIG. 10. Infarcted cortex.

the former organ and $\mathbf{1 3}$ for the latter and his photographs do show some resemblance to those figured here.

The soluble protein content of the developing human brain has not been examined previously and more work is necessary before any useful opinions can be formulated. The lack of good differentiation between the different protein fractions found in these experiments was also observed by Palladin (1957) in his work on soluble proteins from the brains of cow embryos.

Among other reports concerning oedematous cerebral tissue are those of Kaps (1954) who found albumin in the white matter but not in the cortex, whereas half of the cases examined here did show the presence of albumin in the cortex. Tomonaga (1959) found some increase of protein in fractions 5 and 6 and Kiyota (1959b) also examined the soluble proteins from eight brains showing oedema. He described 'simple' and 'complicated' oedema, finding in the former a normal protein pattern, while in the latter abnormal protein fractions were present such as serum albumin in the brain extracts. The results recorded in this paper indicate a considerable amount of albumin to be present in the white matter in all cases and in the cortex in some cases. Further, although there was some increase in the L.D.H. content in the extracted fluid, no increase in G.O.T. was found. This may well suggest the possibility that both the water and albumin were extracellular 
rather than intracellular and might therefore support the contention of Davson and Spaziani (1959) that such a space does exist. It is of interest that the soluble cerebral proteins from the infarcted brain, although containing albumin, yet did not yield a greater enzyme content than normal so that there may well be two types of oedema as Kiyota suggested.

When cerebral oedema takes place around a tumour or an abscess albumin appears to exude through the capillary walls, which may be damaged, into the extracellular space. Some of the albumin might be adsorbed on to the astrocytes with resulting damage to them or to their enzyme systems thereby causing rupture of some of these cells, so liberating L.D.H. but little G.O.T. This appears to be somewhat surprising, for McArdle, Thompson, and Webster (1960) have shown that lysolecithin liberated G.O.T. from incubated brain slices even though a very slight amount of true cholinesterase was liberated. At the present time it is not known exactly where in human nerve cells these enzymes are located but McArdle and his colleagues have demonstrated that in the rat's brain there is a considerable amount of G.O.T. in the heavy mitochondria.

Enzyme studies on proteins separated by starch electrophoresis have also been made by Hughes (1959; 1961) from normal and abnormal muscle. It is of interest to note that Wieme (1959) found a multiplicity of the L.D.H. group of enzymes in the tissues of the rat and mouse using agar electrophoresis. This appears to be true for the liver, kidney, and muscle, and it will be interesting to apply procedures similar to those of Wieme to the brain. Kowlessar, Pert, Haeffner, and Sleisenger (1959) have shown that serum alkaline phosphatase migrated in two bands when examined by starch electrophoresis. They also found that 5-nucleotidase was located in one serum protein fraction only. It has also been shown electrophoretically that there may be alterations in G.O.T. in the different protein fractions in diseases of different pathology (Emmriclo and Zimmermann, 1959).

It is too early to speculate upon the value of these investigations in human disease but they map eventually yield a better understanding of the nature of the serious problem of brain oedema which is found in a variety of conditions.

My thanks are due to the many pathologists who have helped in this investigation by sending me brains foP examination. Mr. R. Shortman has given me expert $\vec{t}$ technical assistance and to him I am very grateful, as I anf to Mr. J. A. Mills for his photographic skill.

\section{REFERENCES}

Booij, J. (1957). Acta physiol. pharmacol. neerl., 6, 648.

Cumings, J. N. (1959). J. clin. Path., 12, 489.

Davson, H., and Spaziani, E. (1959). J. Physiol. (Lond.), 149, 135. Emmrich, R., and Zimmermann, S. (1959). Klin. Wschr., 37, 935. Greenberg, D. M. (1929). J. biol. Chem., 82, 545.

Hofmann, G., and Schinko, H. (1956). Klin Wschr., 34, 86.

Hughes, B. P. (1959). Biochem. biophys. Res. Comm., 1, 194.

- (1961). Nature (Lond.), 188, 1028.

Kaps, G. (1954). Arch. Psychiat. Nervenkr., 192, 115.

Karcher, D., Lowenthal, A., and Sande, M. van (1958). Clin. Chin?̣ Acta, 3, 76. Sande, M. van, and Lowenthal, A. (1959). J. Neurochem., 135.

Kessel, M. (1959). In Protides of the Biological Fluids, Proc. 6t Colloquium, Bruges, 1958, p. 108, ed. H. Peeters. Elsevi户 Publishing Co., Amsterdam.

King, J. (1958). J. med. Lab. Technol, 15, 17.

Kiyota, K. (1959a). J. Neurochem., 4, 202.

(1959b). Ibid, 4, 209.

Kowlessar, O. D., Pert, J. H., Haeffner, L. J., and Sleisenger, M. $\overrightarrow{\overline{6}}$ (1959). Proc. Soc. exp. Biol. (N.Y.), 100, 191.

McArdle, B., Thompson, R. H. S., and Webster, G. R. $(1960)$ J. Neurochem., 5, 135.

Palladin, A. V. (1957). In Metabolism of the Nervous System, p. 456 ed. D. Richter. Pergamon Press, London.

Robertson, D. M. (1957). J. Neurochem., 1, 358.

(1960). Ibid, 5, 145.

Sande, M. van, Karcher, D., and Lowenthal, A. (1959). In Protide of the Biological Fluids, Proc. 6th Colloquium, Bruges, 195\%. p. 223, ed. H. Peeters. Elsevier Publishing Co., Amsterdan?

Schwarzmann, V. (1959). Rev. franc. Et. clin. biol., 4, 265.

Smithies, O. (1955). Biochem. J., 61, 629.

Tomonaga, M. (1959). Fukuoka Acta med., 50, 3373

Wieme, R. J. (1959). Bull. Soc. Chim. biol. (Paris), 41, 235.

Wróblewski, F., and LaDue, J. S. (1955). Proc. Soc. exp. Biol. (N. Y. P 90, 210 